\title{
Biochemical properties and drug resistance of Aeromonas salmonicida in Finland
}

\author{
Varpu Hirvelä-Koski ${ }^{1}$, Perttu Koski ${ }^{1}$, Hillevi Niiranen ${ }^{2}$ \\ ${ }^{1}$ National Veterinary and Food Research Institute, Regional Laboratory Oulu, PO Box 517, SF-90101 Oulu, Finland \\ ${ }^{2}$ Syvälahdentie, SF-72330 Tiitilänkylä, Finland
}

\begin{abstract}
The biochemical properties of 105 Aeromonas salmonicida (AS) strains were examined in order to find criteria for distinguishing between 'typicals' and 'atypicals' and for further subdividing the 'atypicals'. One hundred of the strains had been isolated from fish at 35 fish farms and 5 from wild fish between 1986 and 1991. The fishes involved were as follows: lamprey, whitefish, rainbow trout, salmon, sea trout, brown trout, arctic char, lake trout, grayling, dace and roach. Typical (AS subsp. salmonicida) and atypical AS strains could be differentiated using 10 biochemical tests: production of acid from saccharose, salicin, $\alpha$-methyl-D-glucoside, L-arabinose and arbutin, production of gas from glucose and maltose, hydrolysis of aesculin, haemolysis, and hydrolysis of Tween 80 . Biochemically, the atypical isolates could not be classified as any of the proposed subspecies and could not be clearly subdivided. All of the AS strains were sensitive to oxolinic acid, trimethoprim-sulpha, chloramphenicol and nitrofurantoin. Oxytetracycline-resistant typical strains were isolated from 9 of the farms.
\end{abstract}

KEY WORDS: Aeromonas salmonicida B Biochemical properties · Atypical strains

\section{INTRODUCTION}

Aeromonas salmonicida subsp. salmonicida has been repeatedly isolated in Finland since 1986, $20 \mathrm{yr}$ after the first report of atypical $A$. salmonicida (AS) in Finland (Ojala 1966). Typical AS appeared first in the Baltic Sea area (Rintamäki \& Koski 1987) and its spread to inland waters was controlled from 1986 onwards mainly by restricting the transfer of live fish and eggs from the sea. Despite this, furunculosis has spread gradually to many inland farms.

The control measures taken in Finland were directed against typical AS infections, because it is these infections that have serious economic consequences for fish farming. It is very important, therefore, to be able to differentiate between typical and atypical strains of AS. There are numerous articles discussing the taxonomy of AS (McCarthy 1977, McCarthy \& Roberts 1980, Paterson et al. 1980, Popoff 1984, Böhm et al. 1986, Whittington et al, 1987. Wichardt et al. 1989, Olivier \& Moore 1990, Toranzo et al. 1991). In this study the biochemical profiles of typical and atypical AS strains isolated in Finland were compared and their antimicrobial sensitivities determined

\section{MATERIAL AND METHODS}

Bacteria. A total of 105 AS strains were examined. The bacterial strains used here were selected from a culture collection of over 200 AS strains, so that only one strain per fish species per year per fish farm was included. These strains had been isolated between 1986 and 1991 from 35 fish farms and from 5 wild fish. The geographical distribution of the isolates is shown in Fig. 1. Isolations were from both diseased $(\mathbf{n}=79)$ and clinically healthy fish $(\mathrm{n}=26), 12$ of which, including that from a lamprey, were obtained after a stress test (Bullock \& Stuckey 1975), and 7 of which were obtained after enrichment in tryptic soy broth (Hirvelä-Koski et al. 1988). The biochemical criteria 


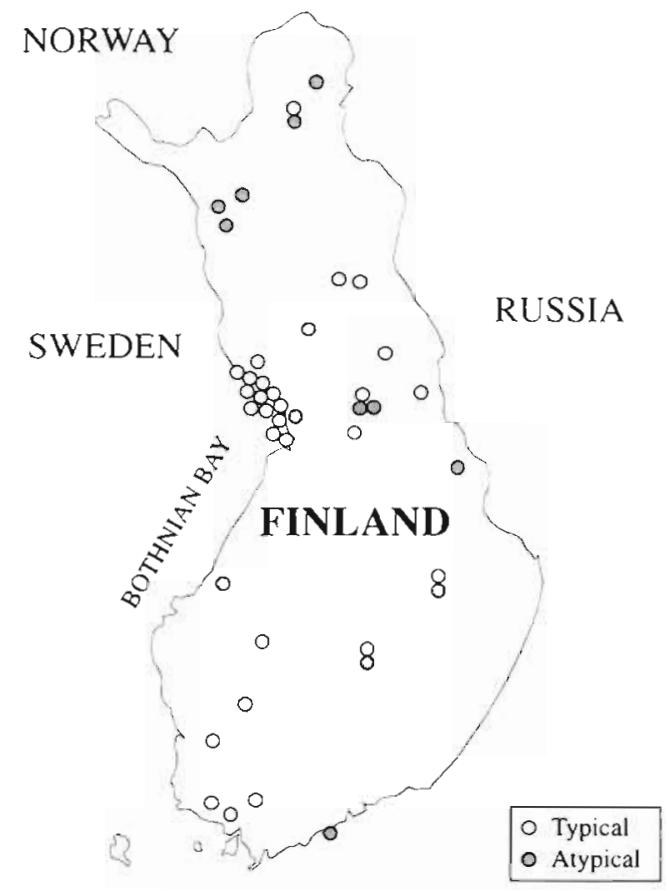

Fig. 1. Location of the isolations of typical and atypical Aeromonas salmonicida strains

used to differentiate between the typical and atypical strains were fermentation of saccharose and gas production from glucose and maltose (Midtlyng et al. 1992).

Typical AS strains $(\mathrm{n}=71)$ were isolated at 27 fish farms and from 2 wild fish, involving the following species. Farmed fish: whitefish Coregonus spp., rainbow trout Oncorhynchus mykiss, salmon Salmo salar (L.), sea trout Salmo trutta m. trutta (L.), brown trout Salmo trutta m. fario (L.), brown trout Salmo trutta m. lacustris (L.), arctic char Salvelinus alpinus (L.), lake trout Salvelinus namaycush Walbaum and grayling Thymallus thymallus (L.); wild fish: whitefish and dace Leuciscus leuciscus (L.).

The lampreys $(n=106)$ were examined with the stress test. Prior to the isolation of the bacterium, these fish had been kept at a fish farm where furunculosis had been detected in rainbow trout.

The atypical AS strains ( $\mathrm{n}=34$ ) were isolated from 11 fish farms and 3 wild fish, representing the following species. Farmed fish: whitefish, rainbow trout, sea trout, brown trout, arctic char and grayling; wild fish: grayling, dace and roach Rutilus rutilus (L.).

Biochemical tests. The oxidase test was performed with the Spot test reagent (Difco). Motility was examined in a 'hanging drop' preparation after 1 to $2 \mathrm{~d}$ of incubation at $22^{\circ} \mathrm{C}$ on blood agar.

Production of acid: $1 \%(\mathrm{w} / \mathrm{v})$ solutions of glucose, sucrose, D-xylose, mannitol, maitose, salicin, trehalose or arbutin were added to a basic broth consisting of $10 \mathrm{~g}$ neopeptone, $10 \mathrm{~g}$ tryptone and $5 \mathrm{~g} \mathrm{NaCl}$ in $1000 \mathrm{ml}$ of water; pH 7.5. Bromthymol blue $(0.0016 \%$ $\mathrm{w} / \mathrm{v}$ ) was used as an indicator of acid production. Fermentation of glucose was verified in glucose broth covered with a layer of paraffin. Gas production in glucose and maltose broth was demonstrated using an inverted Durham tube.

Indole production was detected by means of Kovac's reagent in a broth consisting of $3 \mathrm{~g}$ Bacto tryptone and $1.5 \mathrm{~g} \mathrm{NaCl}$ in $300 \mathrm{ml}$ of water; $\mathrm{pH} 7.5$.

Hydrolysis of aesculin was verified in a broth consisting of $1.2 \mathrm{~g}$ meat extract, $2.0 \mathrm{~g}$ peptone, $1.0 \mathrm{~g} \mathrm{NaCl}$, $1.0 \mathrm{~g}$ aesculin and water $(200.0 \mathrm{ml}) ; \mathrm{pH} 7.4$. The appearance of a black colour after the addition of 5 drops of $2 \%(\mathrm{w} / \mathrm{v})$ iron III citrate indicated degradation of aesculin. The nitrate reduction test was performed in a nitrate broth (Difco) according to the manufacturer's instructions.

Haemolysis was tested on both bovine and horse blood agar (tryptic soy agar, CASO, Merck, containing $5 \%$ blood). Hydrolysis of Tween 80 was detected on a modified Shotts-Waltman agar. The medium contained $0.03 \%$ bromthymol blue instead of the $0.0003 \%$ as suggested in the original article by Waltman \& Shotts (1984). Production of a brown, diffusible pigment was detected on both tryptic soy agar (CASO, Merck) and furunculosis agar [10 $\mathrm{g}$ tryptone, $5 \mathrm{~g}$ yeast extract, $1 \mathrm{~g}$ L-tyrosine, $2.5 \mathrm{~g} \mathrm{NaCl}, 15 \mathrm{~g}$ agar and water (1000 ml); $\mathrm{pH} 7.3]$.

Seventy-seven AS strains (47 typical and 30 atypical) were tested on API $50 \mathrm{CHE}$ strips according to the manufacturer's instructions. At least 1 isolate was tested from each farm every year.

The incubation temperature was 20 to $22^{\circ} \mathrm{C}$ for all tests, and the results were recorded daily. A reaction was judged to be negative after $7 \mathrm{~d}$ of incubation, except for the indole test, which was read after $3 \mathrm{~d}$.

Antimicrobial sensitivity. Sensitivities to ampicillin $(33 \mu \mathrm{g})$, cephalothin $(66 \mu \mathrm{g})$, oxytetracycline $(80 \mu \mathrm{g})$, oxolinic acid $(10 \mu \mathrm{g})$, sulphonamides $(240 \mu \mathrm{g})$, trimethoprim-sulpha $(5.2+240 \mu \mathrm{g})$, chloramphenicol $(60 \mu \mathrm{g})$ and nitrofurantoin $(260 \mu \mathrm{g})$ were tested by the agar diffusion method using Antibiotic sulfonamide sensitivity-test agar (Merck) and Neo-sensitabs tablets (Rosco). The inoculum was prepared in saline $10.9 \%$ $\mathrm{NaCl}$ ) to give a semiconfluent growth. After an incubation of $2 \mathrm{~d}$ at $22^{\circ} \mathrm{C}$, the diameters of the inhibition zones were measured using a sliding caliper. The results were interpreted according to the instructions given by the manufacturer of the tablets (Casals \& Pringler 1991). Because of their limited growth on the sensitivity-test agar, all of the atypical strains were tested on blood agar. 


\section{RESULTS}

This is the second report on Aeromonas salmonicida subsp. salmonicida in lampreys and it confirms that of Wood (1967), who refers to the lamprey's ability to carry the furunculosis bacterium during migration. We examined 106 lampreys by the stress test and found that 5 of them harboured typical AS in their kidneys. One of the lampreys also proved to be a carrier of Yersinia ruckeri.

\section{Biochemical characteristics}

All of the AS strains were small, Gram-negative, non-motile, oxidase-positive rods that fermented glucose. The typical strains appeared ellipsoid in Gramstained smears, while the atypical strains tended to be more slender and long. A strong tendency for the AS cells to autoagglutinate was easily discernible in the 'hanging drop' preparations.

All the AS strains were positive within $7 \mathrm{~d}$ in the tests for acid production from ribose, D-glucose, D-fructose, mannitol and maltose, while all strains were negative in the following tests: acid production from erythritol, $D$-arabinose, D-xylose, L-xylose, adonitoil, $\beta$-methylxyloside, L-sorbose, rhamnose, dulcitol, inositol, $\alpha$ methyl-D-mannoside, amygdaline, lactose, melibiose, inuline, melezitose, xylitol, $\beta$-gentiobiose, D-turanose, $D$-tagatose, D-fucose, L-fucose, D-arabitol, L-arabitol and 2-ceto-gluconate. In the indole test all strains were negative after $3 \mathrm{~d}$ of incubation.

In addition to the fermentation of saccharose and gas production from glucose and maltose, typical and atypical strains differed in 7 biochemical tests: acid production from aesculin, salicin, $\alpha$-methyl-D-glucoside, arbutin and L-arabinose, Tween hydrolysis and haemolysis (Tables 1 \& 2). Acid production from saccharose and $\alpha$-methyl-D-glucoside, gas production from glucose and maltose, Tween hydrolysis, and haemolysis were rapid reactions and could be read reliably after 2 to $3 \mathrm{~d}$. Production of acid from L-arabinose was slow, and it took $7 \mathrm{~d}$ before all typical strains were positive (Table 1). The salicin, arbutin and aesculin reactions showed differences between API 50 CHE and the tube tests (Tables $1 \& 2$ ).

All typical strains showed $\beta$-haemolysis on bovine blood agar (Table 2), but the reaction was weaker than on horse blood agar. Atypical strains showed no haemolysis in $2 \mathrm{~d}$. All but 4 typical strains produced a brown, diffusible pigment within 2 to $3 \mathrm{~d}$ at $22^{\circ} \mathrm{C}$ on both tryptic soy agar and furunculosis agar, but when the incubation temperature was lowered to 15 or $4{ }^{\circ} \mathrm{C}$, all of the typical strains produced pigment. Twentythree atypical strains produced pigment on furunculo- sis agar, but 6 of them (26\%) were negative on tryptic soy agar. Eleven atypical strains produced no pigment on tryptic soy nor on furunculosis agar at $22^{\circ} \mathrm{C}$.

There were differences in the biochemical test results between achromogenic and pigment-producing atypical strains (Table 3). However, none of these tests was unique to one or other of the 2 groups. All of our atypical isolates grew well on tryptic soy agar, and none of them required more than $2 \mathrm{~d}$ for visible growth.

Table 1. Aeromonas salmonicida. Percentage of typical and atypical strains with a positive reaction in API $50 \mathrm{CHE}$

\begin{tabular}{|c|c|c|c|}
\hline Biochemical test & $\begin{array}{l}\text { Incubation } \\
\text { time } \\
\text { (d) }\end{array}$ & $\begin{array}{l}\text { Typical } \\
\text { strains } \\
(\mathrm{n}=47)\end{array}$ & $\begin{array}{c}\text { Atypical } \\
\text { strains } \\
(\mathrm{n}=30)\end{array}$ \\
\hline Glycerol & $\begin{array}{l}2 \\
7\end{array}$ & $\begin{array}{r}72 \\
100\end{array}$ & $\begin{array}{l}60 \\
80\end{array}$ \\
\hline L-arabinose & $\begin{array}{l}2 \\
7\end{array}$ & $\begin{array}{r}13 \\
100\end{array}$ & $\begin{array}{l}0 \\
0\end{array}$ \\
\hline Ribose & $\begin{array}{l}2 \\
7\end{array}$ & 100 & $\begin{array}{r}97 \\
100\end{array}$ \\
\hline Galactose & $\begin{array}{l}2 \\
7\end{array}$ & 100 & $\begin{array}{l}73 \\
77\end{array}$ \\
\hline D-fructose & $\begin{array}{l}2 \\
7\end{array}$ & 100 & $\begin{array}{r}97 \\
100\end{array}$ \\
\hline D-mannose & $\begin{array}{l}2 \\
7\end{array}$ & $\begin{array}{l}72 \\
96\end{array}$ & $\begin{array}{r}97 \\
100\end{array}$ \\
\hline Mannitol & $\begin{array}{l}2 \\
7\end{array}$ & 100 & $\begin{array}{r}87 \\
100\end{array}$ \\
\hline Sorbitol & $2-7$ & 0 & 3 \\
\hline$\alpha$-methyl-D-glucoside & $2-7$ & 100 & 0 \\
\hline N-acetyl-glucosamine & $\begin{array}{l}2 \\
7\end{array}$ & 100 & $\begin{array}{l}23 \\
37\end{array}$ \\
\hline Arbutin & $2-7$ & 91 & 0 \\
\hline Aesculin & $2-7$ & 100 & 0 \\
\hline Salicin & $2-7$ & 100 & 0 \\
\hline Cellobiose & $\begin{array}{l}2 \\
7\end{array}$ & $\begin{array}{l}0 \\
0\end{array}$ & $\begin{array}{r}0 \\
17\end{array}$ \\
\hline Maltose & $\begin{array}{l}2 \\
7\end{array}$ & 100 & $\begin{array}{r}83 \\
100\end{array}$ \\
\hline Saccharose & $2-7$ & 0 & 100 \\
\hline Trehalose & $\begin{array}{l}2 \\
7\end{array}$ & $\begin{array}{r}0 \\
30\end{array}$ & $\begin{array}{l}27 \\
53\end{array}$ \\
\hline D-raffinose & $\begin{array}{l}2 \\
7\end{array}$ & $\begin{array}{l}0 \\
0\end{array}$ & $\begin{array}{r}0 \\
13\end{array}$ \\
\hline Amidon & $\begin{array}{l}2 \\
7\end{array}$ & 100 & $\begin{array}{l}57 \\
87\end{array}$ \\
\hline Glycogen & $\begin{array}{l}2 \\
7\end{array}$ & 100 & $\begin{array}{l}57 \\
90\end{array}$ \\
\hline D-lyxose & $\begin{array}{l}2 \\
7\end{array}$ & $\begin{array}{l}0 \\
0\end{array}$ & $\begin{array}{l}0 \\
3\end{array}$ \\
\hline Gluconate & $\begin{array}{l}2 \\
7\end{array}$ & 100 & $\begin{array}{r}3 \\
23\end{array}$ \\
\hline 5-keto-gluconate & $\begin{array}{l}2 \\
7\end{array}$ & $\begin{array}{l}0 \\
3\end{array}$ & $\begin{array}{l}0 \\
0\end{array}$ \\
\hline
\end{tabular}


Table 2. Aeromonas salmonicida. Percentage of strains with a positive reaction in the tube tests or on agar plates (methods described in the text)

\begin{tabular}{|c|c|c|c|}
\hline Biochemical test & $\begin{array}{c}\text { Incubation } \\
\text { time } \\
\text { (d) }\end{array}$ & $\begin{array}{l}\text { Typical } \\
\text { strains } \\
(n=71)\end{array}$ & $\begin{array}{l}\text { Atypical } \\
\text { strains } \\
(\mathrm{n}=34)\end{array}$ \\
\hline Saccharose & $\begin{array}{c}2-3 \\
7\end{array}$ & $\begin{array}{l}0 \\
0\end{array}$ & 100 \\
\hline D-xylose & $\begin{array}{c}2-3 \\
7\end{array}$ & $\begin{array}{l}0 \\
0\end{array}$ & $\begin{array}{l}0 \\
0\end{array}$ \\
\hline Indole & $2-3$ & 0 & 0 \\
\hline Aesculin & $\begin{array}{c}2-3 \\
7\end{array}$ & $\begin{array}{r}96 \\
100\end{array}$ & $\begin{array}{l}0 \\
3\end{array}$ \\
\hline Mannitol & $\begin{array}{c}2-3 \\
7\end{array}$ & 100 & $\begin{array}{l}94 \\
97\end{array}$ \\
\hline Maltose & $\begin{array}{c}2-3 \\
7\end{array}$ & 100 & $\begin{array}{l}35 \\
56\end{array}$ \\
\hline Salicin & $\begin{array}{c}2-3 \\
7\end{array}$ & $\begin{array}{l}10 \\
58\end{array}$ & $\begin{array}{l}0 \\
0\end{array}$ \\
\hline Trehalose & $\begin{array}{c}2-3 \\
7\end{array}$ & $\begin{array}{r}3 \\
31\end{array}$ & $\begin{array}{l}29 \\
29\end{array}$ \\
\hline Arbutin & $\begin{array}{c}2-3 \\
7\end{array}$ & $\begin{array}{r}97 \\
100\end{array}$ & $\begin{array}{l}0 \\
0\end{array}$ \\
\hline Gas from glucose & $\begin{array}{c}2-3 \\
7\end{array}$ & 100 & $\begin{array}{l}0 \\
0\end{array}$ \\
\hline Gas from maltose & $\begin{array}{c}2-3 \\
7\end{array}$ & 100 & $\begin{array}{l}0 \\
0\end{array}$ \\
\hline Nitrate reduction & $\begin{array}{c}2-3 \\
7\end{array}$ & 100 & $\begin{array}{l}91 \\
91\end{array}$ \\
\hline Haemolysis & $2-3$ & 100 & 0 \\
\hline Tween 80 hydrolysis & 2 & 100 & 0 \\
\hline
\end{tabular}

Table 3. Aeromonas salmonicida. Percentage of pigment producing ( $\mathrm{n}=19)$ and achromogenic $(\mathrm{n}=11)$ atypical strains with a positive reaction in fermentation tests (API $50 \mathrm{CHE}$ ) and nitrate reduction test after incubation of $7 \mathrm{~d}$

\begin{tabular}{|lrc|}
\hline Biochemical test & Pigment + & Pigment - \\
\hline Glycerol & 100 & 45 \\
Galactose & 100 & 64 \\
N-acetyl-glucosamine & 5 & 91 \\
Trehalose & 68 & 27 \\
D-raftinose & 0 & 36 \\
Amidon & 100 & 64 \\
Glycogen & 100 & 73 \\
Nitrate reduction & 100 & 73 \\
\hline
\end{tabular}

\section{Antimicrobial sensitivity}

All of the AS strains were sensitive to oxolinic acid, trimethoprim-sulpha, chloramphenicol and nitrofurantoin (Table 4). All of the typical strains were sensitive to ampicillin and cephalothin, whereas most of the atypical strains were resistant to these antimicrobials. Resis-
Table 4. Aeromonas salmonicida. Percentage of sensitive (AS) strains in sensitivity testing by the agar diffusion method

\begin{tabular}{|lcc|}
\hline Antimicrobial & Typical $^{\mathrm{a}}$ & Atypical $^{\mathrm{b}}$ \\
\hline Ampicillin & 100 & 12 \\
Cephalothin & 100 & 12 \\
Oxytetracycline & 70 & 100 \\
Oxolinic acid & 100 & 100 \\
Sulphonamides & 83 & 22 \\
Trimethoprim sulpha & 100 & 100 \\
Chloramphenicol & 100 & 100 \\
Nitrofurantoin & 100 & 100 \\
& & \\
an $n=71$ for ampicillin and cephalothin and 69 for other \\
antimicrobials & & \\
${ }^{b} \mathrm{n}=34$ for ampicillin and cephalothin and 32 for other \\
antimicrobials
\end{tabular}

tance to oxytetracycline occurred only among the typical strains, but resistance to sulphonamides was found in both groups

\section{DISCUSSION}

Our results regarding the usefulness of selected biochemical tests for the classification of AS are in agreement with earlier reports (Paterson et al. 1980, Popoff 1984, Böhm et al. 1986, Whittington et al. 1987. Wichardt et al. 1989, Olivier et al. 1990, Toranzo et al. 1991), but we also found acid production from L-arabinose and hydrolysis of Tween 80 to be useful in differentiating between typical and atypical strains. According to Popoff (1984), all AS strains were positive in the Tween 80 degradation test, while we found all the typical isolates to be positive and the atypical ones negative, as reported by Austin et al. (1989). Nielsen et al. (1993) also reported the fermentation of L-arabinose by typical strains.

There were differences between the tube test and the API $50 \mathrm{CHE}$ results with respect to the aesculin, salicin, maltose, mannitol and arbutin reactions. The slow aesculin, salicin, maltose and mannitol reaction in the tube tests can be explained by the use of a light inocula in these tests. The negative arbutin reactions of some typical strains in API $50 \mathrm{CHE}$ (Table 1) are more difficult to explain. One difference between the tube and API $50 \mathrm{CHE}$ tests lies in the amount of arbutin present, $1 \%$ and $0.77 \%$, respectively.

The production of brown pigment has been regarded as an important diagnostic feature of typical strains (Popoff 1984) even though this was questioned by McCarthy et al. (1980). We found 4 typical strains which did not produce pigment at $22^{\circ} \mathrm{C}$ even when the incubation period was extended to $3 \mathrm{wk}$. At a lower 
incubation temperature pigment production was easily detected in $2 \mathrm{wk}$. Incubation at supra-optimal temperatures has been reported to alter certain biochemical characteristics of AS (McIntosh \& Austin 1991). All the 4 strains were biochemically similar to each other except for trehalose fermentation, and they originated from the same area in southern Finland. Koppang et al. (1993) also isolated in Norway from salmon an Aeromonas salmonicida subsp. salmonicida, which was 'atypical' in that it did not produce pigment.

Furunculosis agar showed its superiority over tryptic soy agar for detecting pigment production by atypical strains, as 6 atypical strains which were negative on tryptic soy agar showed distinct pigment production on furunculosis agar.

Our results indicate that the differentiation between typical and atypical strains should be based on a combination of biochemical tests. We have found it useful to use both bovine blood agar and modified ShottsWaltman agar for primary culturing of samples. After $2 \mathrm{~d}$ of incubation, presumptive differentiation of typical and atypical strains can be made on the basis of the sucrose reaction, Tween hydrolysis, haemolysis, and pigment production.

Even though both typical and atypical AS strains have regularly been isolated all over the country since 1986, there are few published articles on Finnish isolates. Rintamäki \& Valtonen (1991) reported the discovery of both atypical and typical AS strains at 5 fish farms in northern and central Finland. The results of the biochemical tests were similar to ours, except that negative results in the nitrate reduction test and some positive reactions in lactose test were reported by these authors

The classification of atypical AS strains is still under discussion. In Bergey's Manual, Aeromonas salmonicida is divided into 3 subspieces: salmonicida, masoucida and achromogenes. There have been some proposals for new subspecies of AS on the basis of biochemical properties, e.g. subsp. smithia (Austin et al. 1989). Our atypical isolates could not be classified into any of these subspecies. According to McCarthy et al. (1980), atypical strains isolated from non-salmonid fish formed a phenotypically distinct group which they called $A$. s. subsp. nova, but we did not find any differences in biochemical test results between isolates from different fish species, nor could our isolates be classified as the subsp. nova described by Böhm et al. (1986).

Results of DNA:DNA reassociation analyses and plasmid content appear to indicate that the typical strains form a homogenous group while there is more diversity among atypical strains (Bast et al. 1988, Belland \& Trust 1988, 1989, Toranzo et al. 1991). Even though some authors have found distinct biotypes among atypical strains on the grounds of genetic data, the biochemical properties of these strains were not reported (Belland \& Trust 1988, 1989).

Oxytetracycline, oxolinic acid and trimethoprimsulpha are the antimicrobials used most often to treat AS infections in Finnish fish farms. Among the isolates tested in this study resistance was found only to oxytetracycline, the resistant strains being isolated from 9 of the 35 fish farms.

Sensitivity testing of atypical non-pigmented strains was complicated by the fact that blood agar had to be used because growth was limited on the sensitivity test medium. Also, it was very difficult to standardize the inoculum strength because of the strong tendency of the atypical strains to autoagglutinate. If the inoculum was too strong and the growth therefore too vigorous, there were problems in interpreting the results as there were very small colonies within the inhibition zone. This weak growth was ignored.

The results of this study support the findings of previously published reports, that typical AS strains form a biochemically homogeneous group. The atypical strains are a more heterogeneous group and proved to be very difficult to classify using biochemical tests. DNA based methods could be of great use in characterization of these pathogens.

Acknowledgements. The skilled technical assistance of Anne Hummastenniemi, Marja Moisiomäki, Ulla Niemi, Arja Väliaho and Ritva Pykälistö is greatly appreciated. We thank Dr Marja-Liisa Hänninen for reading and commenting on the manuscript.

\section{LITERATURE CITED}

Austin, D. A., McIntosh, D., Austin, B. (1989). Taxonomy of fish associated Aeromonas spp., with the description of Aeromonas salmonicida subsp. smithia subsp. nov. System. appl. Microbiol. 11:277-290

Bast, L., Daly, J. G., DeGrandis, S. A., Stevenson, R. M. V. (1988). Evaluation of profiles of Aeromonas salmonicida as epidemiological markers of furunculosis infections in fish J. Fish Dis. 11: 133-145

Belland, R. J., Trust, T J (1988). DNA: DNA reassociation analysis of Aeromonas salmonicida. J. gen. Microbiol. 134 307-315

Belland, R. J., Trust, T. J. (1989). Aeromonas salmonicida plasmids: plasmid-directed synthesis of proteins in vitro and in Escherichia coli minicells. J. gen. Microbiol. 135: 513-524

Böhm, K. H., Fuhrmann, H., Schlotfeldt, H.-J., Körting, W. (1986). Aeromonas salmonicida from salmonids and cyprinids - serological and cultural identification. J. vet. Med. B 33: 777-783

Bullock, G. L., Stuckey, H. M. (1975). Aeromonas salmonicida: detection of asymptomatically infected trout. Progrve Fish-Cult. 37: 237-239

Casals, J. B., Pringler, N. (1991). Antibacterial/antifungal sensitivity testing using Neo-Sensitabs, 9th edn. Rosco Diagnostica, Taastrup

Hirvelä-Koski, V., Koski, P., Kuoppamäki, T. (1988). Enrichment in tryptic soy broth for the detection of Aeromonas salmonicida from the kidney of carrier fish. Bull. Eur. Ass 
Fish Pathol. 8: 85-86

Koppang, E. O., Fjolstad, M., Melgård, B. (1993). Identufıcation of an atypical Aeromonas salm. ssp. salm. isolated from salmon in Norway. In: Proc. 6th int. Conf. Eur. Ass. Fish Pathol., September 5-10, Brest. European Association of Fish Pathologists, p. 26

McCarthy, D. H. (1977). The identification and significance of atypical strains of Aeromonas salmonicida. Bull. Off. int. Epiz. 87: 459-463

McCarthy, D. H., Roberts, R. J. (1980). Furunculosis of fish the present state of our knowledge. In: Droop, M. R. Jannasch, H. W. (eds.) Advances in aquatic microbiology, Vol. 2. Academic Press, London, p. 293-341

McIntosh, D., Austin, B. (1991). Atypical characteristics of the salmonid pathogen Aeromonas salmonicida. J. gen. Microbiol. 137: 1341-1343

Midtlyng, P. J., Helgason, S., Jansson, E., Mortensen, A., Rimaila-Pärnänen, E. (1992). Nordic manual for the surveillance and diagnosis of diseases in farmed salmonids. Nordiske Seminar- og Arbejdsrapporter 545. Nordisk Ministerråd, Copenhagen

Nielsen, B. (1993). Aeromonas salmonicida. Faeno- og genotypisk karakterisering samt udvikling af furunkulosevacciner. Academic diss. Den Kgl. Veterinaer- og landbohojskole, Copenhagen

Ojala, O. (1966). Isolation of an anaerogenic bacterium resembling Aeromonas salmonicida in spawning lake trouts. Bull. Off. int. Epiz. 65: 793-804

Olivier, G., Moore, A. R. (1990). Taxonomy and virulence of atypical strains of Aeromonas salmonicida isolated from salmonid and non-salmonid fish. In: Proc. Int. Conf. on Bacterial Diseases of Fish. Stirling. Institute of Aquaculture, Univ. of Stirling, p. 6

Responsible Subject Editor: T. Evelyn, Nanaimo, B.C., Canada
Paterson, W. D., Douey, D., Desautels, D. (1980). Relationships between selected strains of typical and atypical Aeromonas salmonicida, Aeromonas hydrophila and Haemophilus piscium. Can. J. Microbiol. 26: 588-598

Popoff, M. (1984). Aeromonas. In: Krieg, N. R., Holt, J. G. (eds.) Bergey's manual of systematic bacteriology, Vol. 1 Williams \& Wilkins, Baltimore, p. 545-550

Rintamäki, P., Koski, P. (1987). Outbreaks of furunculosis in northern Finland. In: Stanmark, A., Malmberg, G. (eds.) Parasites and diseases in natural waters and aquaculture in nordic countries. Naturhistoriska riksmuseet, Stockholm, p. 121-128

Rintamäki, P. Valtonen, T. (1991). Aeromonas salmonicida in Finland: pathological problems associated with atypical and typical strains. J. Fish Dis. 14: 323-331

Toranzo, A. E., Santos, Y., Nunez, S., Barja, J. L. (1991). Biochemical and serological characteristics, drug resistance and plasmid profiles of Spanish isolates of Aeromonas salmonicida. Gyobyo Kenkyu 26: 55-60

Waltman, D. W. Shotts, E. B. (1984). A medium for the isolation and differentation of Yersinia ruckeri. Can. J. Fish. Aquat. Sci. 41: 804-806

Whittington, R. J., Gudkovs, N., Carrigan, M. J., Ashburner L. D., Thurstan, S. J. (1987). Clinical, microbiological and epidemiological findings in recent outbreaks of goldfish ulcer disease due to atypical Aeromonas salmonicida in south-eastern Australia. J. Fish Dis. 10: 353-362

Wichardt, U.-P., Johansson, N., Ljungberg, O. (1989). Occurrence and distribution of Aeromonas salmonicida infections on Swedish fish farms, 1951-1987 J. Aquat. Anim Health 1. 187-196

Wood, J. W. (1967). Salmon disease report. Wash. State Dept Fish. A. Rep. 77: 111-112

Manuscript first received: May 31, 1993

Revised version accepted: September 1, 1994 